\title{
CHROMOBACTERIUM SP. FROM THE TROPICS: DETECTION AND DIVERSITY OF PHYTASE ACTIVITY
}

\section{Patrícia S. Costa, Andréa M.A. Nascimento, Cláudia I. Lima-Bittencourt, Edmar Chartone-Souza, Fabrício R. Santos,} Adlane Vilas-Boas

Departamento de Biologia Geral, Instituto de Ciências Biológicas, Universidade Federal de Minas Gerais, Belo Horizonte, MG, Brasil.

Submitted: March 05, 2010; Returned to authors for corrections: April 30, 2010; Approved: June 21, 2010.

\begin{abstract}
Phytases are a group of enzymes that catalyze phytic acid hydrolysis with release of phosphorus $(\mathrm{P})$. The ability of Chromobacterium sp. to produce phytase was detected in 115 out of 118 candidate bacteria isolated from different Brazilian biomas. This is the first report revealing the genus Chromobacterium as phytase producer.
\end{abstract}

Key words: Chromobacterium sp., diversity, phytase, phytate, tropical bacteria

Phytase (myo-inositol hexakisphosphate phosphohydrolase) is a generic term that identifies several structurally different enzymes belonging to a phosphatase subgroup which catalyzes phytate hydrolysis (17). Phytates are important agents of eutrophication in aquatic ecosystems specially for increasing phosphorus (P) availability in water bodies close to livestock due to the inability of monogastric animals to absorb these wide-distributed compounds (19). Biotechnological applications of phytases include their supplement in swine and fish feed, environmental protection, and as plant growth-promoting agents (5). Phytases are ubiquitous in nature and have been found in bacteria belonging to the genera Bacillus (18), Escherichia (6), Rahnella, Pseudomonas (10), among others (8, 16). The search for different types of phytases is desired since their use in the industry requires different physicochemical properties (5).

The genus Chromobacterium encompasses free-living Gram-negative bacteria, and, currently, six species are recognized: $C$. violaceum (type species), C. subtsugae, $C$. aquaticum, C. haemolyticum, C. pseudoviolaceum and C. piscinae. Chromobacterium sp. isolates from three different tropical ecosystems (Savannah, Atlantic and Amazon Rain Forests) exhibited high physiological and genetic diversity when compared to the $C$. violaceum ATCC $12472^{\mathrm{T}}$ type species, from Malaysia (11), which has been used for genome sequencing analysis (2). Therefore, although in the genome annotation of the type species ORFs showing homology to known phytases were not found, we decided to evaluate the ability of the genus Chromobacterium to produce phytase.

A total of 118 Chromobacterium sp. isolates, belonging to our private collection, were recovered from water and soil from Brazilian Savannah (Serra do Cipó National Park, Minas Gerais State), Atlantic Rain Forest (Rio Doce State Park) and the Amazon Forest (Negro River); they have been previously identified based on the 16S rRNA gene sequencing analysis $(11,12)$. The nucleotide sequences of these isolates are deposited in the GenBank database with accession numbers EF077669-72, EF077674-77, EF077681-87, EF077689-92, EF077698-99, EF077702-03, EF077705, GU216171-74, GU216177-91, GU216195, GU216197, GU216199, 
GU216202， GU216205-08， GU216210， GU216212-13, GU216216-21, HM236059-75, HM236077-99 and HM236100-17.

All phytase assays were performed using a sodium salt phytic acid (Sigma, St. Louis, Mo.) and all solutions were filter-sterilized prior to addition to autoclaved media. For qualitative phytase production assays, a standard inoculum of approximately $10^{4} \mathrm{CFU} / \mathrm{ml}$ of an overnight culture was used. Qualitative screening tests were initially performed using the SM medium having phytate as the only source of $\mathrm{P}(1.5 \%$ glucose; $0.5 \% \quad \mathrm{NH}_{4} \mathrm{NO}_{3} ; 0.5 \% \quad \mathrm{MgSO}_{4} .7 \mathrm{H}_{2} \mathrm{O} ; 0.05 \% \quad \mathrm{KCl}$; $\mathrm{FeSO}_{4} \cdot 7 \mathrm{H}_{2} \mathrm{O} \quad 0.001 \% ; \mathrm{MnSO}_{4} \cdot \mathrm{H}_{2} \mathrm{O} 0.001 \%$ and $1.5 \%$ agar), plus $0.8 \mathrm{mmol} \mathrm{l}^{-1}$ phytic acid, $13 \mathrm{mmol} \mathrm{l}^{-1} \mathrm{Na}_{2} \mathrm{HPO}_{4}$ and 13 mmol $1^{-1} \mathrm{NaH}_{2} \mathrm{PO}_{4}$ ), incubated at $28^{\circ} \mathrm{C}$ for 6 days and then scored for phytase activity based on the method of Bae et al. (1) with modifications: $2 \% \mathrm{Cl}_{2} \mathrm{Co}$ was poured over the SMphytic acid agar plates for $5 \mathrm{~min}$, after which $6.63 \% \mathrm{Na}_{2} \mathrm{MoO}_{4}$ and $0.44 \% \quad \mathrm{NaVO}_{3} \cdot \mathrm{H}_{2} \mathrm{O} \quad(1: 1)$ were added. This method distinguishes halos produced by phytase from those due to other phosphatases. The type species failed to grow on SMphytate medium and so did some Brazilian isolates. We thus used a low concentration of inorganic phosphate salts in the SM-phytate medium as described by Fredrikson et al. (4) since these authors and others (8) pointed out that expression of phytase may occur after addition of inorganic $\mathrm{P}$ to the medium enough only to allow initial bacterial growth. E. coli ATCC 25922, used as a positive control for phytase activity, exhibited a halo of $15.5 \mathrm{~mm}$ while no halo was observed around $C$. violaceum ATCC $12472^{\mathrm{T}}$ colonies (not shown). Interestingly, most of the 118 Chromobacterium sp. isolates (97\%) were phytase producers (Table 1). Variability in phytase production among the isolates was indicated by the different sizes of the clearing zones around the bacteria (6 to $18 \mathrm{~mm}$ ). The Brazilian isolates were divided into three classes of phytase production, according to diameter of halos: low (6-9.9 mm), medium (10$15.9 \mathrm{~mm})$ and high $(16-18 \mathrm{~mm})$. Association between classes of phytase production and origin of the isolates was not observed.

Table 1. Grouping of phytase-producing Brazilian Chromobacterium sp. isolates according to halo size.

\begin{tabular}{|c|c|c|}
\hline $\begin{array}{l}\text { Production } \\
\text { level }^{\text {a }}\end{array}$ & $\begin{array}{l}\text { Production of } \\
\text { phytase (diameter } \\
\text { of halos }-\mathbf{m m})^{b}\end{array}$ & Isolates \\
\hline Low (39) & $6-9.9$ & $\begin{array}{l}\text { 58AtF, 59AtF,61AtF, 20BS, 24BS,25BS,78BS,79BS,84BS, 85BS, 87BS, } \\
\text { 88BS, 98BS, 100BS, 101BS,102BS, 108BS,109BS*, 116BS, 118BS, 120BS, } \\
\text { 121BS,122BS,136BS,143BS*,156BS,157BS, 159BS*, 164BS, 172BS, } \\
\text { 175BS,177BS*,178BS, 179BS, 180BS, 181BS, 182BS,53AmF,55AmF, }\end{array}$ \\
\hline Medium (63) & $10-15.9$ & $\begin{array}{l}\text { 37BS,46AmF,47AmF,49AmF,45AmF,60AtF,80BS,81BS,83BS, 86BS, 91BS, } \\
\text { 137BS,140BS,141BS*,142BS,144BS,145BS, 149BS, 174BS, 13BS, 14BS, } \\
\text { 40BS, 65BS,66BS,95BS, 103BS, 104BS, 115BS, 135BS, 173BS, 153BS, } \\
\text { 139BS,99BS,170BS, 71BS, 163BS, 125BS, 119BS, 117BS, 110BS, 93BS, } \\
\text { 77BS,64BS,21BS*,165BS,176BS,148BS,147BS,128BS,129BS,89BS*,90BS, } \\
\text { 54AmF,74BS*,76BS,111BS,124BS,130BS,158BS,131BS,126BS,69BS,27BS }\end{array}$ \\
\hline High (8) & $16-18$ & 1BS,72BS, 167BS,123BS,63BS,56AtF,4BS*,155BS* \\
\hline
\end{tabular}

${ }^{a}$ Production level defined solely on the size of clearing zones; numbers in parenthesis indicate number of isolates of each group. BS - Brazilian Savannah; AmF - Amazon Rain Forest; AtF - Atlantic Rain Forest ${ }^{\mathrm{b}}$ Size of the colonies was 4 to 5 mm; * Isolates deficient in violacein production.

Quantitative phytase production was tested by inoculating isolates in SM-phytic acid medium at $28^{\circ} \mathrm{C}$ for $24 \mathrm{~h}$. The assay was performed as described by Bae et al. (1) with dilution of the cultures to have the same cell density. Release of inorganic phosphate was measured in a spectrophotometer $\left(\mathrm{OD}_{700} \mathrm{~nm}\right)$ and one unit of phytase activity (U) was defined as the amount of enzyme that produces $1 \mu \mathrm{mol}$ of inorganic phosphate per hour at $27^{\circ} \mathrm{C}(15)$. Violacein has a wide reading spectrum 431 to $699 \mathrm{~nm}$ - (13), and, consequently, could interfere with phytase spectrophotometric readings which were done at 
$700 \mathrm{~nm}$. Therefore, this limitation restricted the number of isolates analyzed to ten, which were those Chromobacterium that did not produce the purple pigment. A purified fungal phytase (a gift of BASF, Brazil) was used as the standard (not shown). Most Chromobacterium isolates showed phytase acitivities (Table 2) higher than the E. coli ATCC 25922 control strain $\left(8.8 \mathrm{U} \mathrm{mL}^{-1}\right)$. Isolate $41 \mathrm{BS}$ exhibited the highest phytase activity $\left(12.4 \mathrm{U} \mathrm{mL}^{-1}\right)$, while the lowest phytase activity was observed in isolate $177 \mathrm{BS}\left(7.4 \mathrm{U} \mathrm{mL}^{-1}\right)$, both from Brazilian savannah.

Table 2. Phytase activity of Chromobacterium sp. isolates

\begin{tabular}{|c|c|}
\hline Isolate - Accession number ${ }^{\text {a }}$ & Phytase activity $\left(\mathbf{U}^{\cdot} \mathrm{ml}^{-1}\right)^{\mathrm{b}}$ \\
\hline 143 BS - GU216199 (L) & 10.2 \\
\hline 177 BS - GU216177 (L) & 7.4 \\
\hline 109 BS - GU216173 (L) & 8.5 \\
\hline 159 BS - GU216208 (L) & 11.0 \\
\hline 141 BS - HM236085 (M) & 12.4 \\
\hline $21 \mathrm{BS}-\mathrm{EF} 077699(\mathrm{M})$ & 11.1 \\
\hline 89 BS - GU216173 (M) & 10.2 \\
\hline 74 BS - HM236111 (M) & 8.8 \\
\hline 4 BS - EF077687 (H) & 11.1 \\
\hline 155 BS - GU216205 (H) & 10.4 \\
\hline E. coli ATCC 25922 & 8.8 \\
\hline
\end{tabular}

a Letters in parenthesis indicate classification of Chromobacterium $s p$. isolates according to the qualitative test: low (L), medium $(\mathrm{M})$ and high $(\mathrm{H})$ producers. E.coli ATCC 25922 - positive phytase producer control.

${ }^{\mathrm{b}}$ One unit of phytase activity (U) was defined as the amount of enzyme that produces 1 $\mu \mathrm{mol}$ of phosphate per hour at $27^{\circ} \mathrm{C}$.

Phytase activity has been widely found among microorganisms such as bacteria, yeasts and filamentous fungi. The Proteobacteria phylum include most phytase-producing bacteria although the $\beta$-proteobacteria class, which the genus Chromobacterium belongs to, bears only two phytase-producer genera, Burkholderia and Acidovora (7). Although there was no evidence for phytase genes in the annotated genome of $C$. violaceum ATCC $12472^{\mathrm{T}}$ type species (2), our study showed in vitro phytase production in Chromobacterium sp. isolates from several Brazilian ecosystems. To our knowledge, this is the first report of phytase-producing isolates in the genus Chromobacterium.

Some Chromobacterium isolates that had been classified as low producers in the qualitative screen exhibited high enzymatic activity. This apparently conflicting result may have arisen due to technical reasons intrinsic to each methodology. Such type of problem has been reported in the determination of antimicrobial activity where differences in the sensitivity profile of microorganisms were observed depending on whether liquid or solid media had been used; this has been a concern, for example, of the Clinical and Laboratory Standards Institute (3). In the quantitative assay, bacteria were grown in liquid medium, thus phytate was more readily available allowing easier degradation. Another possibility is that some isolates secreted lower amounts of enzyme in solid media. It is known that in liquid media bacteria express different factors compared to growth in solid media; one example is the capsular polysaccharide which may interfere with antibacterial activity of drugs such as lysostaphin (9). It is also possible that different phytases vary in their diffusion rates through agar. In 
any case, we consider that the qualitative method should be used only as an initial screening and should not be used as a precise comparative method for phytase production.

Variability in phytase production was a remarkable feature of the isolates and diversity has been observed for other characteristics in Chromobacterium (11). Variation in genome sizes within the same species is common in bacteria. According to Parkhill and Thomson (17) the genome of Escherichia coli can vary over $1 \mathrm{Mb}$ among natural isolates. There is indication that much of this diversity is due to the presence of bacteriophages (14). We presume that the same phenomenon may have happened in Chromobacterium allowing for different gene diversity among natural isolates which would explain the phytase diversity observed in this study. Therefore, we suggest that the $C$. violaceum type species, even though it was the one chosen for genome sequencing (2), is not a representative of the isolates found in nature. The type species may in fact lack a phytase gene, differently from the several isolates analyzed here. Since phytases are enzymes grouped mainly for their structure and catalytic properties rather than sequence homology $(8,7)$ individual gene analysis is not a very straightforward approach and genomic studies may be more appropriate.

The biotechnological potential of $C$. violaceum has been explored and includes bioremediation, production of PHAs (polyhydroxyalkanoates), chitinases, elastases and violacein, a purple pigment which has antimicrobial activity against protozoans (2). Additional possibilities for biotechnological applications arised with the sequencing of $C$. violoceum genome (2). Considering the diversity observed in Brazilian isolates, this potential seems to be greater than previously expected. Additional experiments are necessary to evaluate the potential of phytases from Brazilian isolates for commercial prospects. Genome sequencing of our Brazilian isolates are planned and this would certainly shed some light on several biological and ecological aspects of this genus.

\section{ACKNOWLEDGEMENTS}

This work was supported by a grant from the National
Council for Technological and Scientific Development (Conselho Nacional de Desenvolvimento Científico e Tecnológico, CNPq) and Fundação de Amparo à Pesquisa de Minas Gerais (FAPEMIG). We thank BASF, Brazil, for the sample of Aspergillus phytase.

\section{REFERENCES}

1. Bae, H.D.; Yanke, L.J.; Cheng, K.J.; Selinger, L.B. (1999). A novel staining method for detecting phytase activity. J Microbiol Methods. 39: 17-22.

2. Brazilian National Genome Project Consortium (2003). The complete genome sequence of Chromobacterium violaceum reveals remarkable and exploitable bacterial adaptability. Proc Natl Acad Sci. 100: 11660-11665.

3. Clinical and Laboratory Standards Institute (2006). Methods for antimicrobial dilution and disk susceptibility testing of infrequently isolated or fastidious bacteria. Approved guideline. First Edition.

4. Fredrikson, M.; Andlid, T.; Haikara, A.; Sandberg, A.S. (2002). Phytate degradation by micro-organisms in synthetic media and pea flour. $J$ Appl Microbiol. 93: 197- 204.

5. Jorquera, M.; Martinez, O.; Maruyama, F.; Marschener, P.; Mora, M.L. (2008). Current future biotechnological applications of bacterial phytases and phytase-producing bacteria. Microbes Environ. 23:182-191.

6. Greiner, R.; Konietzny, U.; Jany, K.D. (1993). Purification and characterization of two phytases from Escherichia coli. Arch Biochem Biophys. 303: 107-113.

7. Hungria, M.; Astolfi-Filho, S.; Chueire, L.M.O.; Nicolás, M.F.; Santos, E.B.P.; Bulbol, M.R.; Souza-Filho, A.; Assunção, E.N.; Germano, M.G.; Vasconcelos, A.T.R. (2005). Genetic characterization of Chromobacterium isolates from black water environments in the Brazilian Amazon. Lett Appl Microbiol. 41: 17-23.

8. Konietzny, U.; Greiner, R. (2002). Molecular and catalytic properties of phytate-degrading enzymes (phytases). Int J Food Sci Technol. 37: 791812 .

9. Kusuma, C.; Jadanova, A.; Chanturiya, T.; Kokai-Kun, J.F. (2006). Lysostaphin resistant variants of Staphylococcus aureus demonstrate reduced fitness in vitro and in vivo. Antimicrob Agents Chemother. 51: 475-482.

10. Irving, G.C.; Cosgrove, D.J. (1971). Inositol phosphate phosphatases of microbiological origin. Some properties of a partially purified bacterial (Pseudomonas sp.) phytase. Aust J Biol Sci. 24: 547-57.

11. Lima-Bittencourt, C.I.; Astolfi-Filho, S.; Chartone-Souza, E.; Santos, F.R.; Nascimento, A.M.A. (2007). Analysis of Chromobacterium sp. natural isolates from different Brazilian ecosystems. BMC Microbiol. 7: $1-9$.

12. Lima-Bittencourt, C.I.; Costa, P.S., Hollatz, C.; Raposeiras, R.; Santos, F.R.; Chartone-Souza, E.; Nascimento, A.M.A. (2010). Comparative biogeography of Chromobacterium from the neotropics. Antonie van 
Leewenhoek

13. Logan, N.A.; Moss, M.O. (1992). Identification of Chromobacterium, Janthinobacterium and Iodobacter species. Soc Appl Bacteriol Techn. Series. 29: 183-192.

14. Ohnishi, M.; Kurokawa, K.; Hayashi, T. (2001). Diversification of Escherichia coli genomes: are bacteriophages the major contributors? Trends Microbiol. 10: p. 481- 485.

15. Palacios, M.C.; Haros, M.; Rosell, C.M.; Sanz, Y. (2005). Characterization of an acid phosphatase from Lactobacillus pentosus: regulation and biochemical properties. J Appl Microbiol. 98: 229-237.

16. Pandey, A.; Szakacs, G.; Soccol, C.R.; Rodriguez-Leon, J.A.; Soccol,
V.T. (2001). Production, purification and properties of microbial phytases. Bioresour Technol. 77: 203-14.

17. Parkhill, J.; Thomson, N. (2003). Evolutionary strategies of human pathogens. Cold Spring Harb Symp Quant Biol. 68: 151-8.

18. Powar, V.K.; Jagannathan, V. (1982). Purification and properties of phytate-specific phosphatase from Bacillus subtilis. J Bacteriol. 151: 1102-1108.

19. Vats, P.; Sahoo, D.K.; Banerjee, U.C. (2004). Production of phytase (myo- inositolhexakisphosphate phosphohydrolase) by Aspergillus niger van Teighem in laboratory-scale fermenter. Biotechnol Prog. 20: 737743. 